\title{
The Role of FGL2 in the Pathogenesis and Treatment of Hepatitis C Virus Infection
}

\author{
Itay Shalev, Ph.D., Nazia Selzner, M.D., Ph.D., Ahmed Helmy, M.D., \\ Katharina Foerster, M.D., Ph.D., Oyedele A. Adeyi, M.D., David R. Grant, M.D., \\ and Gary Levy, M.D.* \\ Multi Organ Transplant Program, University Health Network, University of Toronto, Toronto, Canada
}

\begin{abstract}
Chronic hepatitis $\mathrm{C}$ virus (HCV) infection is a leading cause of liver disease worldwide and remains the most common indication for liver transplantation. The current standard of care leads to a sustained viral response of roughly $50 \%$ of treated patients at best. Furthermore, anti-viral therapy is expensive, prolonged, and associated with serious side-effects. Evidence suggests that a poor response to treatment may be the result of a suppressed anti-viral immunity due to the presence of increased numbers and activity of $\mathrm{CD}_{4}{ }^{+} \mathrm{CD} 25^{+} \mathrm{Foxp}_{3}{ }^{+}$regulatory $\mathrm{T}$ cells (Treg cells). We and others have recently identified fibrinogen-like protein 2 (FGL2) as a putative effector of Treg cells, which accounts for their suppressive function through binding to $\mathrm{Fc}$ gamma receptors $(\mathrm{Fc} \gamma \mathrm{R})$. In an experimental model of fulminant viral hepatitis, our laboratory showed that increased plasma levels of FGL2 pre- and post-viral infection were predictive of susceptibility and severity of disease. Moreover, treatment with antibody to FGL2 fully protected susceptible animals from the lethality of the virus, and adoptive transfer of wild-type Treg cells into resistant $f g l 2$-deficient animals accelerated their mortality post-infection. In patients with HCV infection, plasma levels of FGL2 and expression of FGL2 in the liver correlated with the course and severity of the disease. Collectively, these studies suggest that FGL2 may be used as a biomarker to predict disease progression in HCV patients and be a logical target for the development of novel therapeutic approaches for the treatment of patients with HCV infection.
\end{abstract}

KEY WORDS: FGL2, Treg, immunity, regulation, HCV, MHV-3

\section{INTRODUCTION}

Hepatitis $\mathrm{C}$ virus (HCV) infection is a leading cause of liver disease with an estimated 200 mil- lion people infected worldwide. ${ }^{1}$ If untreated, the inflammatory response to the virus promotes hepatic fibrosis and development of cirrhosis

\footnotetext{
Abbreviations: DC, dendritic cells; Fc $\mathrm{R}$, Fc gamma receptors; FGL2, fibrinogen-like protein 2; FRED, fibrinogen-related domain; HBV, hepatitis B virus; HCV, hepatitis C virus; IL, interleukin; MHC, major histocompatibility complex; MHV-3, murine hepatitis virus strain 3 ; SVR, sustained virological response; Treg cells, Foxp $3{ }^{+} \mathrm{CD}_{4}{ }^{+} \mathrm{CD} 25^{+}$regulatory $\mathrm{T}$ cells.

Citation: Shalev I, Selzner N, Helmy A, Foerster K, Adeyi OA, Grant DR, Levy G. The Role of FGL2 in the Pathogenesis and Treatment of Hepatitis C Virus Infection. RMMJ 2010;1(1):e0004. doi:10.5041/RMMJ.10004

Copyright: (C) 2010 Shalev et al. This is an open-access article. All its content, except where otherwise noted, is distributed under the terms of the Creative Commons Attribution License (http://creativecommons.org/licenses/by/3.o), which permits unrestricted use, distribution, and reproduction in any medium, provided the original work is properly cited.

Conflict of interest: No potential conflict of interest relevant to this article was reported.

* To whom correspondence should be addressed. E-mail: glfgl2@attglobal.net
} 
which may be complicated by hepatocellular cancer (HCC). As a result, HCV infection has now become the most common indication for liver transplantation. Unfortunately, HCV reinfection of the graft occurs universally and is associated with an aggressive course in a proportion of patients, leading to graft cirrhosis in $10 \%-30 \%$ of recipients within 3-5 years. ${ }^{2}$ Therefore, the $5^{-}$ year survival of HCV-positive liver transplant recipients is overall significantly lower than that of HCV-negative patients. ${ }^{2}$

The goal of HCV treatment is to prevent hepatic (cirrhosis and hepatocellular cancer) and extrahepatic complications by permanently eradicating the virus. At present, the standard of care for treating chronic HCV is the combination of weekly subcutaneous injections of pegylated interferon- $\alpha$ (PegIFNa) and ribavirin (RBV) for 24-48 weeks, depending on the viral genotype. Treatment with PegIFNa/RBV needs to be prolonged (6-12 months), and compliance is a necessity. To add to this, the treatment is expensive and is associated with significant side-effects. ${ }^{3}$ The rate of a sustained viral response (SVR) following this therapy is at best $50 \%$ overall. $4^{-6}$

Presently, a number of host and viral factors are associated with response to therapy. These include race, viral genotype, alcohol intake, and liver histology (amount of steatosis and stage of fibrosis).7-10 Genetic diversity of the host contributes to the outcome of HCV infection and antiviral treatment. The sequencing of the human genome together with the development of new technologies, such as gene expression profiling and high-throughput protein analysis, has provided opportunities for rapid and accurate characterization of gene expression in tissues, and for the detection of individual host genetic polymorphisms. For example, our group has recently identified consistent patterns of gene expression in the pre-treatment liver biopsies which were predictive of treatment response. ${ }^{11}$ Identification of biomarkers to predict anti-viral treatment response would provide important diagnostic reagents in the management of HCV and may allow for the development of novel therapeutics for patients with HCV infection.

\section{IMMUNITY TO HCV}

Both the innate and adaptive immune responses are important for viral clearance. ${ }^{12}$ In innate immunity, a number of innate effector cells and cytokines have been shown to be important for clearance of HCV infection. Natural killer (NK) cells play a key role in the innate anti-viral immune responses to HCV. ${ }^{12}$ Additionally, production of type 1 interferons (IFN) is important in first-line defense against $\mathrm{HCV}$ infection. The non-structural protein $3\left(\mathrm{NS}_{3}\right) / 4 \mathrm{~A}$ protease and $\mathrm{NS}_{5} \mathrm{~A}$ of HCV have been shown to impair both IFN production and IFN responsiveness, which would contribute to the inability to mount effective immune responses to HCV.9

In adaptive immunity, robust $\mathrm{CD}^{+}$and $\mathrm{CD} 8^{+}$ $\mathrm{T}$ cell responses are associated with clearance of HCV. ${ }^{13}$ Impaired $\mathrm{CD}_{4}{ }^{+}$and $\mathrm{CD}^{+} \mathrm{T}$ cell responses are known to be associated with chronic HCV. Patients who have spontaneously recovered from $\mathrm{HCV}$ infection maintain virus-specific $\mathrm{CD}_{4}^{+}$and $\mathrm{CD}^{+} \mathrm{T}$ cell responses that are readily detectable in their blood. ${ }^{13-15}$ These responses contribute to control and/or clearance of HCV as shown in a non-human primate model of HCV infection. In this model, depletion of either $\mathrm{CD}_{4}{ }^{+}$or $\mathrm{CD}^{+} \mathrm{T}$ cells prior to challenge with HCV leads to chronic infection with high viral titers. ${ }^{16}$

Patients with chronic HCV typically display narrowly focused and weak HCV-specific T cell responses. ${ }^{17,18}$ Virus-specific $\mathrm{T}$ cells isolated from the peripheral blood of these patients appear to have lost most of their ability to proliferate and to produce cytokines (interleukin (IL)-2 and IFN- $\gamma$ ). In addition, $\mathrm{CD}^{+} \mathrm{T}$ cells display reduced cytotoxicity. In the absence of pre-existing defects in adaptive immunity, such as immunosuppression associated with malnutrition, human immunodeficiency virus (HIV) co-infection, or renal failure, this $\mathrm{CD}^{+} \mathrm{T}$ cell dysfunction has been attributed to high levels of persisting viral antigens.

An additional factor that influences the functional capacity of the $\mathrm{CD} 8+\mathrm{T}$ cell pool is activation and stimulation by $\mathrm{CD}^{+}{ }^{+} \mathrm{T}$ helper cells. $\mathrm{CD}^{+}{ }^{+} \mathrm{T}$ cells are involved either by directly activating dendritic cells (DC) and $\mathrm{CD}^{+} \mathrm{T}$ cells via CD40-dependent co-stimulation or by indirectly supporting $\mathrm{B}$ cell and $\mathrm{CD} 8+\mathrm{T}$ cell responses by secretion of cytokines, such as IL-4 and IL-2. In the mouse model of lymphocytic choriomeningitis virus (LCMV)-induced hepatitis, $\mathrm{CD}^{+} \mathrm{T}$ cell function was dependent on $\mathrm{CD} 4^{+} \mathrm{T}$ helper cell responses. ${ }^{19}$ That was shown by the observation that $\mathrm{CD}^{+} \mathrm{T}$ cell function was reduced in the absence of $\mathrm{CD}_{4}{ }^{+} \mathrm{T}$ cells. ${ }^{19}$ Moreover, as shown in the non-human primate model of HCV infection, protective $\mathrm{CD}^{+} \mathrm{T}$ cell immunity may require $\mathrm{CD}^{+}{ }^{+} \mathrm{T}$ helper cells not only in the primary infection but also after recovery, at the time of rechallenge. ${ }^{20}$ 
Treatment of acute infection with PegIFN results in high rates of virus clearance, in part by an efficient early stimulation of anti-HCV $\mathrm{CD} 4^{+}$ Th1 responses. ${ }^{21,22}$ It has been recently demonstrated that chronic HCV-infected patients with mild or absent disease had circulating memory $\mathrm{CD}_{4}{ }^{+} \mathrm{T}$ cells that recognized $\mathrm{NS}_{3}$ and $\mathrm{HCV}$ core antigens in contrast to those with severe disease. ${ }^{23}$ Similarly, chronic HCV patients who responded to treatment with IFN also demonstrate an increased Th1 cytokine profile and persistent viral-specific $\mathrm{CD}_{4}{ }^{+}$responses, responses which are weak or absent in non-responders. ${ }^{24}$

\section{ROLE OF TREG CELLS IN THE PATHOGENESIS OF HCV INFECTION}

Foxp $3^{+}{ }^{C D} 4^{+} \mathrm{CD}_{25}{ }^{+}$regulatory $\mathrm{T}$ cells (Treg cells), which constitute $5 \%-10 \%$ of peripheral $\mathrm{CD}_{4}{ }^{+} \mathrm{T}$ cells in humans, are known to be actively engaged in the negative control of physiological and pathological immune responses. ${ }^{25}$

Treg cells have a broad $\mathrm{T}$ cell receptor repertoire that can recognize various self and non-self antigens. It has been suggested that the immune system employs Treg cells to maintain selftolerance by suppressing the activation and expansion of self-reactive lymphocytes that might otherwise cause autoimmune disease. ${ }^{25}$ A controlled balance between initiation and downregulation of the host immune response is vital in maintenance of immune homeostasis. A number of studies have suggested that depletion or reduction of Treg cells leads to enhanced immune responses against various infectious pathogens including HCV.26,27 A higher proportion of Treg cells was found in patients with chronic HCV infection when compared with successfully treated and/or healthy controls. ${ }^{26,28-30}$ In vitro depletion of these cells results in increased HCV-specific T cell responsiveness. ${ }^{28,29}$ Thus, Treg cells appear to suppress the effector response of virus-specific T cells in patients with chronic HCV infection.

Treg cells have been shown to exert their suppressive activity through a number of different pathways. Production of immunoregulatory cytokines has been proposed as a major mechanism by which Treg cells mediate their function. Treg cell suppressive cytokines that have been described in the literature include transforming growth factor (TGF)- $\beta$, IL-10, and IL-35. ${ }^{31}$ These molecules have been shown to play a key role in the suppressive activity of Treg cells. ${ }^{31,32}$ Recently, we and others have identified the fibrinogenlike protein 2 (fgl2) as a putative effector gene of Treg cells and other regulatory $\mathrm{T}$ cell subsets, including $\mathrm{CD}^{+}{ }^{+} \mathrm{CD} 45 \mathrm{RC}^{\mathrm{low}} \mathrm{T}$ cells, $\mathrm{CD} 8 \mathrm{aa}^{+} \mathrm{T}$ cells in the intestine, and CD4-CD8- double negative (DN) T cells. ${ }^{31,33-36}$

\section{FIBRINOGEN-LIKE PROTEIN 2 (FGL2)}

FGL2, also known as fibroleukin, was first cloned from cytotoxic $\mathrm{T}$ lymphocytes and was classified as a member of the fibrinogen superfamily due to its homology (36\%) with fibrinogen $\beta$ and $\gamma$ chains. ${ }^{37}$ The $f g l 2$ gene, which has been localized to chromosome 7 and 5 in humans and mice, respectively, is composed of two exons that are separated by one intron. The fgl2 promoter contains cis element consensus sequences for the binding of various transcription factors, including Ets, AP1, Sp1, TCF1, Ikaros, and CEBP. 38

The $f g l 2$ gene encodes a protein of 432 amino acids in mice and 439 amino acids in humans. The deduced protein sequence contains a predicted signal peptide, five $\mathrm{N}$-linked glycosylation sites, and conserved cysteine residues. Under non-reducing conditions the molecular mass of the protein is $250-300 \mathrm{kDa}$, and in reducing condition it is $64-70 \mathrm{kDa}$, indicating that FGL2 in its natural state forms a tetrameric complex. ${ }^{39,40}$ Based on sequence and structural analysis, it is predicted that the encoded protein is composed of two major regions, the N-terminal domain and the carboxyl-terminus. The $\mathrm{N}$ terminal domain is proposed to have a linear conformation due to the presence of $\alpha$-helical region and several conserved cysteine residues, which can promote coiled-coil formation. The 229-amino-acid-long carboxyl-terminus consists of a highly conserved globular domain, known as the fibrinogen-related domain (FRED), that is characteristic of the fibrinogen-related protein superfamily. The overall identity between the mouse and human FGL2 is $78 \%$, but within the FRED domain the two proteins share 90\% homology. ${ }^{41}$

In macrophages and endothelial cells, FGL2 is primarily expressed as a membrane-associated protein (Figure 1), which has prothrombinase activity with the ability to generate thrombin directly from prothrombin. 42 By a combination of site-directed mutagenesis and production of truncated proteins, it was shown that the serine 89 residue of the $\mathrm{N}$-terminal domain is critical for the prothrombinase activity of FGL2.42 FGL2 prothrombinase activity has been implicated in the pathogenesis of various human and experimental models of disease including viral hepatitis, xeno- and allotransplantation rejection, and 


\section{Membrane bound FGL2}

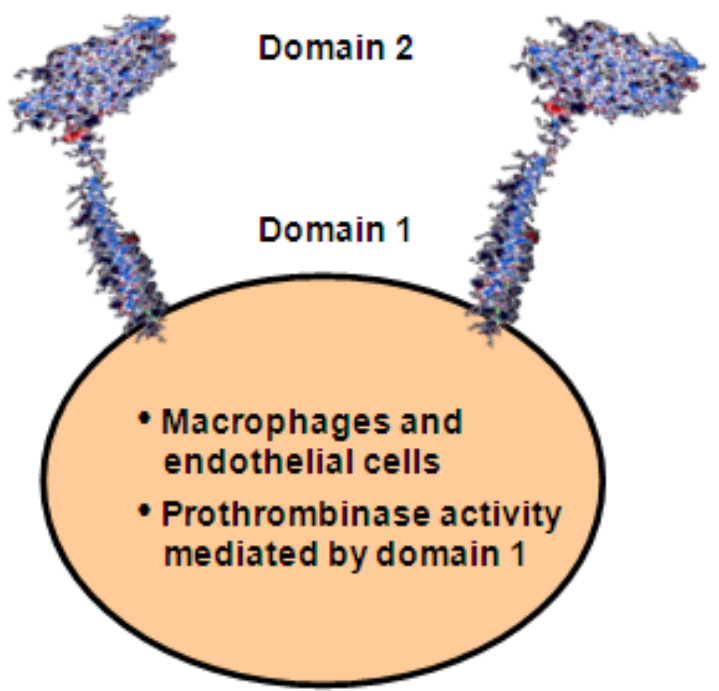

\section{Secreted FGL2}

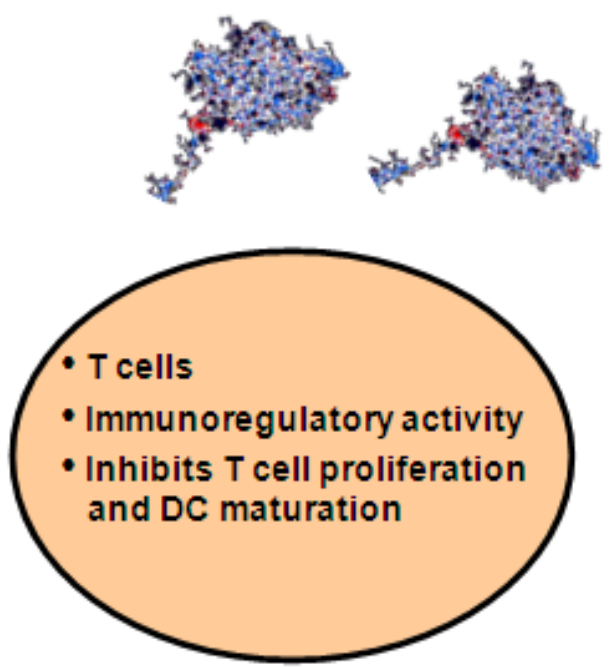

Figure 1. Schematic view of the two forms of FGL2 with their respective function as was previously reported. Macrophages and endothelial cells express a membrane-associated FGL2, which acts as a prothrombinase, while $\mathrm{T}$ cells produce a secreted form of the protein that plays a role in regulation of immune responses. DC, dendritic cells.

fetal loss syndrome.43-46

FGL2 is secreted by regulatory $\mathrm{T}$ cells (Figure 1), inhibits DC maturation and function, and induces B cell apoptosis.35,36,40,47 The C-terminal globular portion of FGL2 has been suggested to account for the immunomodulatory function of the molecule. ${ }^{47}$ FGL2 exerts its regulatory activity by binding to $\mathrm{Fc}$ gamma receptors $(\mathrm{Fc} \gamma \mathrm{R})$ that are expressed differentially on antigenpresenting cells including monocyte/ macrophages, DC, B cells, and endothelial cells. 39 The regulatory activity of FGL2 has been implicated in inhibition of allograft rejection 39 and autoimmunity, 35 and the pathogenesis of experimental and human viral infections, including in patients with HIV, severe acute respiratory syndrome (SARS), and hepatitis B virus. $36,45,48,49$

\section{FGL2 AS A REGULATOR OF IMMUNE RESPONSES}

Although the prothrombinase activity of the membrane-associated FGL2 expressed by macrophages and endothelial cells has been well established by many studies, the exact role of $\mathrm{T}$ cell-secreted FGL2 remains undefined. Recent studies by our group and other laboratories have suggested that FGL2 might be important in the regulation of adaptive immune responses. This would be consistent with the observation that other members of the fibrinogen-related superfamily that contain the FRED domain have previously been shown to have immunoregulatory activity in addition to their role in coagulation. 47 Other members of the fibrinogen-related superfamily include tenascin that can inhibit $\mathrm{T}$ cell activation in response to alloantigens and Con $\mathrm{A}$, a fibrinogen that has the ability to trigger a series of intracellular signaling events and cellular responses upon interaction with integrins and angiopoietins, and ficolins, which have also been shown to have the ability to regulate host immune responses. 47

Clinical studies have also suggested a role for FGL2 in immunoregulation. Kohno et al. showed that expression of $f g l 2$ is down-regulated in patients with both acute and chronic adult $\mathrm{T}$ cell leukemia/lymphoma.50 Patients with acute and chronic hepatitis B infection have been reported to express high levels of FGL2 in their livers. 45 In addition, genomic analysis revealed a polymorphism in the fgl2 gene in patients that are susceptible to SARS and severe periodontitis.48,51 Lastly, a recent study has demonstrated abundant levels of FGL2 protein in livers of patients with hepatocellular carcinoma. ${ }^{2}$ Collectively, these clinical data support the hypothesis that FGL2 might be involved in regulation of immuni- 
ty.

The role of FGL2 in regulation of adaptive immune responses was first shown by Chan et al.,47 who studied the molecular and functional properties of the protein in vitro. A recombinant FGL2, which was generated in a baculovirus expression system, inhibited the proliferation of $\mathrm{T}$ cells in response to stimulation with antiCD3/CD28 antibodies, Con A, and alloantigens. The inhibitory effect of FGL2 on T cells was mediated through suppression of DC maturation, characterized by the inhibition of nuclear factor kappa beta $(\mathrm{NF}-\mathrm{\kappa B})$ translocation to the nucleus resulting in down-regulation of $\mathrm{CD} 80$ and major histocompatibility complex (MHC) class II molecules. The suppressive effects of FGL2 were abrogated by a specific antibody directed against the C-terminal domain of FGL2, strongly suggesting that the carboxyl FRED region accounts for the regulatory activity of the molecule. The recombinant protein also polarized allogeneic $\mathrm{T}$ cell responses towards a Th2 cytokine profile with increased production of IL-10 and IL-4, and decreased secretion of Th1 cytokines, including IFN- $\gamma$ and IL-2.47 In another study, it was shown that the absence of FGL2 was associated with accelerated cellular rejection in a xenotransplant model. 46

\section{FGL2 AS AN EFFECTOR OF REGULATORY T CELLS}

A number of groups have recently reported that regulatory $\mathrm{T}$ cells have increased $f g l 2$ gene transcription as detected by microarray gene analysis. Herman et al. were the first to report increased transcripts of $f g l 2$ in Treg cells isolated from the pancreas of diabetic mice. 34 Subsequent studies by Rudensky et al. have also detected high expression of $f g l 2$ in Treg cells isolated from wild-type $F_{0 x p} 3^{g f p}$ mice and $I L-2^{-/-}$mice. Upregulation of fgl2 expression was observed in Treg cells from $I L-2^{-/-}$mice that were treated with recombinant IL-2 for 24 hours.33 Rudensky and colleagues further showed a positive correlation between Foxp3 and fgl2 expression; however, the expression of fgl2 was not under the direct control of Foxp3.53

In addition to $\mathrm{CD} 4{ }^{+} \mathrm{CD} 25^{+}$Treg cells, other subsets of regulatory $\mathrm{T}$ cells have also been found to express high levels of fgl2. A recent report showed that $\mathrm{CD} 8 \mathrm{aa}^{+}$regulatory $\mathrm{T}$ cells in the intestine of mice over-express $f g l 2$, which was suggested to play a role in the function of these cells.54 Our laboratory has detected high produc- tion of FGL2 protein and fgl2 mRNA in both primary and clones of DN regulatory T cells. Interestingly, high levels of FGL2 were produced by a functional clone of DN T cells, but were undetectable in a non-functional DN T cell clone. Furthermore, increased expression of fgl2 in primary DN T cells correlated with their suppressive activity in vitro. Finally, Anegon et al. found increased expression of $f g l 2$ in $\mathrm{CD}^{+}{ }^{+} \mathrm{CD} 45 \mathrm{RC}^{\text {low }}$ regulatory $\mathrm{T}$ cells that mediate allograft tolerance in a rat transplantation model (personal communication). The role of FGL2 in these different types of regulatory $\mathrm{T}$ cells is currently being evaluated.

In agreement with previous studies, high levels of $f g l 2$ transcripts were detected in Treg cells by real-time polymerase chain reaction (PCR). 35 In fgl2 $/-$ mice, an increased number and percentage of Treg cells were found with a greater expression of Foxp3 compared with $f g \mathrm{l}^{+/+}$Treg cells; however, the suppressive activity of $f g \mathrm{l}^{-/-}$Treg cells was significantly impaired. 35 Furthermore, antibody to FGL2 completely inhibited the activity of fgl2 $2^{+/+}$Treg cells in vitro, strongly supporting the contention that expression of FGL2 accounts for the suppressive activity of Treg cells. 35 Consistent with FGL2 contribution to Treg cell activity, targeted deletion of the gene led to an increase in immune reactivity of DC, T cells and B cells, and the development of autoimmune glomerulonephritis in aged $f g l 2^{-/-}$mice. 35

\section{THE ROLE OF FGL2 IN AN EXPERIMENTAL MODEL OF FULMINANT VIRAL HEPATITIS}

Our laboratory has extensively studied the role of FGL2 prothrombinase in a model of fulminant hepatitis caused by murine hepatitis virus strain 3 (MHV-3). $45,55-58$ Susceptible strains of mice develop a fatal hepatitis that is characterized by intravascular thrombosis and hepatocellular necrosis; resistant strains of mice survive and clear the virus within 10-14 days of infection. Several lines of evidence suggest that induction of FGL2 contributes to the lethality of $\mathrm{MHV}-3$-induced hepatitis. First, only in susceptible BALB/cJ and semi-susceptible $\mathrm{C} 3 \mathrm{H} / \mathrm{eJ}$ mice is there induction of FGL2 by MHV-3.56,59,60 Of interest, BALB/cJ mice, which express high levels of FGL2, uniformly die of liver failure, whereas surviving $\mathrm{C}_{3} \mathrm{H}$ mice that express only moderate levels of FGL2 develop chronic hepatitis (Figure 2 and reference 36 ). In contrast, resistant $\mathrm{A} / \mathrm{J}$ mice, which fail to produce FGL2 following $\mathrm{MHV}-3$ 
infection either in vivo or in vitro, all survive and clear the virus (Figure 2 and reference 36). Second, treatment of susceptible mice with a monoclonal antibody to FGL2 prevents thrombosis, hepatic necrosis, and lethality of MHV-3 infection. ${ }^{36}$ Finally, targeted deletion of $f g l 2$ renders $\mathrm{C}_{57} \mathrm{BL} / 6 \mathrm{~J}$ mice largely resistant to $\mathrm{MHV}-3.45$ At a molecular level, we have defined the active serine 89 site and requirement for phospholipids for prothrombinase activity of membraneassociated FGL2;42 demonstrated that $f g l 2$ is transcriptionally regulated by the nucleocapsid protein $(\mathrm{N})$ of strains of MHV that cause lethal

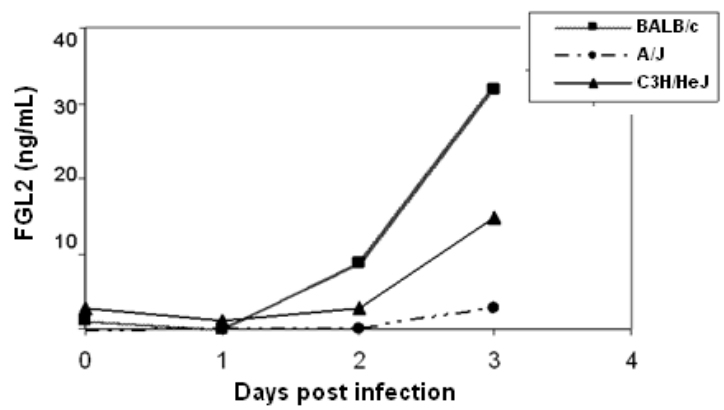

Figure 2. Levels of sFGL2 correlate with resistance and susceptibility in mouse strains following MHV-3 infection. Graph shows the levels of sFGL2 $(\mathrm{ng} / \mathrm{mL})$ in the plasma of different strains of mice following $\mathrm{MHV}-3$ infection.

disease; ${ }^{61-64}$ and shown that the mechanism of lack of $f g l 2$ transcription in resistant $\mathrm{A} / \mathrm{J}$ mice is altered phosphorylation of signal transducer and activation of transcription (STAT) $1 \quad \alpha / \beta$ isoforms. ${ }^{64}$

Recently we have developed an enzyme-linked immunosorbent assay (ELISA) to measure secreted FGL2 (sFGL2) in murine plasma. ${ }^{36}$ This assay was used to analyze plasma samples from both MHV-3 infected susceptible and resistant mice daily from the time of infection to day 8 post-infection. ${ }^{36}$ In our study, plasma levels of sFGL2 correlated with disease progression. MHV-3-susceptible mice expressed markedly elevated levels of sFGL2 over time, correlating with increased numbers of Treg cells, whereas resistant mice had no significant increase in levels of sFGL2 or Treg cells. ${ }^{36}$ Moreover, adoptive transfer of $f g \mathrm{l}^{+/+}$Treg cells into resistant $f g \mathrm{l}^{-/-}$ mice increased their mortality following $\mathrm{MHV}-3$ infection, demonstrating the importance of FGL2 as an effector of Treg cells in experimental viral hepatitis. ${ }^{36}$ These data collectively suggest that disturbances in Treg cell activity or number may be important in the pathogenesis of viral induced liver injury and that monitoring levels of sFGL2 may be of use in predicting outcome to infection.

\section{THE ROLE OF FGL2 IN THE PATHOGENESIS OF HCV INFECTION}

We have developed a sensitive and reproducible ELISA for measurement of sFGL2 in plasma samples in humans. We have established baseline levels of sFGL2 in healthy controls using plasma samples from healthy volunteers tested on two separate occasions. Plasma levels of sFGL2 were then compared to patients with chronic HCV infection as well as patients with non-viral related liver disease (alcohol-induced liver disease). Our data shown in Figure 3 suggest that, in patients with chronic HCV infection, levels of plasma sFGL2 is significantly higher than in patients with alcoholic liver disease, patients with a sustained viral response to anti-viral treatment, and healthy controls (Figure 3). These data demonstrate that in HCV patients, who cleared the virus following anti-viral therapy and

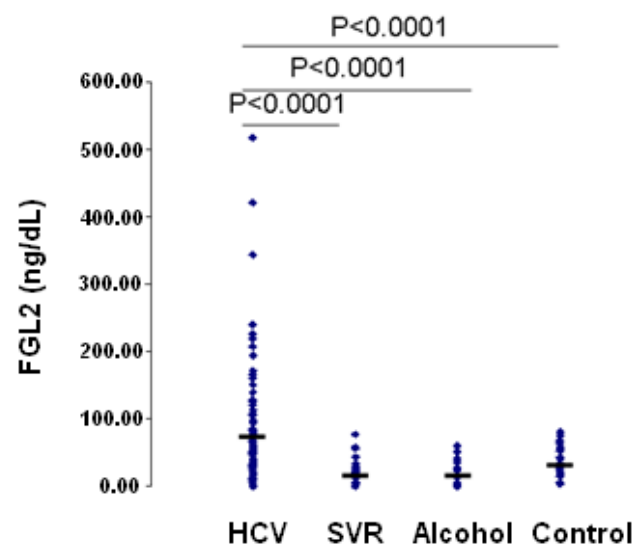

Figure 3. Mean plasma levels of sFGL2 in patients with chronic HCV infection. Ten (10) mL of heparinized blood was collected from 80 patients with chronic HCV infection, who had not received anti-viral therapy. Mean plasma levels of sFGL2 in these patients were compared to 30 healthy controls, 24 patients with inactive alcoholic cirrhosis, and 32 patients with chronic HCV who cleared the virus following successful anti-viral therapy (sustained virological responders (SVR)). Mean plasma levels of sFGL2 were significantly higher in patients with chronic HCV infection $(84.3 \pm 89.1 \mathrm{ng} / \mathrm{mL}, n=80)$ compared to healthy controls $(36.41 \pm 21.9 \mathrm{ng} / \mathrm{mL}, n=30)$, patients with alcoholic cirrhosis $(18.8 \pm 17.4 \mathrm{ng} / \mathrm{mL}, n=24)$, or patients with SVR $(16.6 \pm 19.7 \mathrm{ng} / \mathrm{mL}, n=32)$. 

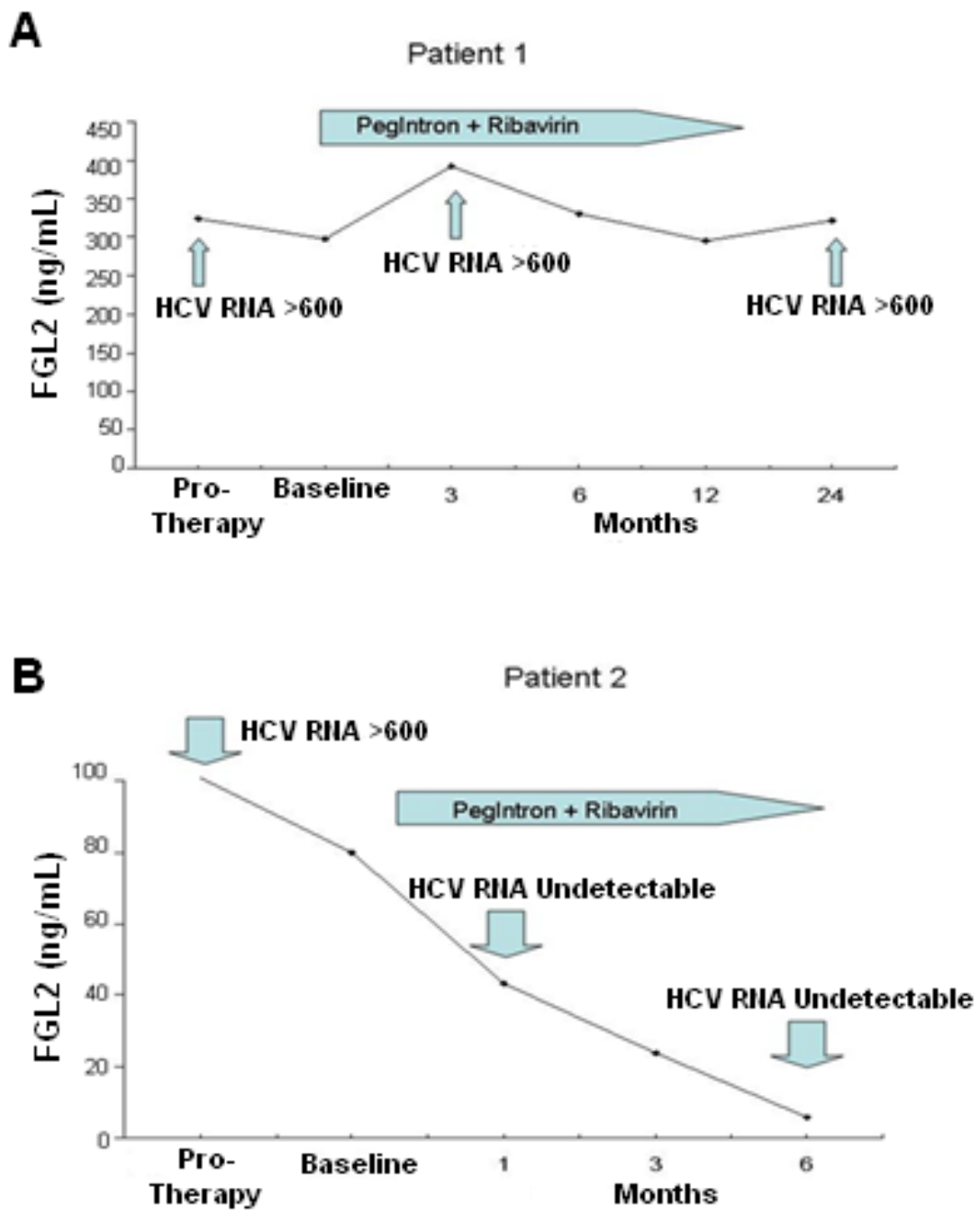

Figure 4. Time course of sFGL2 levels in two patients with chronic HCV infection treated with anti-viral therapy. A) Patient 1 with genotype 1 infection did not respond to 48 weeks of therapy with pegylated interferon and Ribavirin. Plasma sFGL2 levels in this patient were high prior to initiation of therapy, throughout treatment and 6 months after completion of therapy. B) Patient 2 with genotype 2 infection responded to anti-viral therapy. Plasma levels of sFGL2 were low prior to initiation of treatment and fell within 4 weeks of therapy to levels similar to healthy controls and remained very low after completion of therapy.

developed an SVR, levels of sFGL2 return to levels seen in normal healthy controls. Furthermore, the results show that the presence of liver disease alone does not correlate with plasma levels of sFGL2 since patients with alcoholic cirrhosis have levels comparable to the healthy controls. Taken together, these preliminary results indicate that the level of sFGL2 may be a useful biomarker of disease progression and response to therapy in patients with HCV infection.

Preliminary data also demonstrated a signifi- cant difference in plasma levels of sFGL2 between HCV patients with genotype 1 compared to genotype $2 / 3$ patients (120 versus $45 \mathrm{ng} / \mathrm{mL}$ ). The data to date suggest that patients with high levels of plasma sFGL2 $(>150 \mathrm{ng} / \mathrm{mL})$ have a more vigorous form of HCV with a higher probability of being non-responders to anti-viral therapy, whereas patients with levels $<100 \mathrm{ng} / \mathrm{mL}$ are more likely to respond to anti-viral treatment. This is demonstrated in Figure 4, which shows the time-course of sFGL2 levels in two 
representative patients with chronic HCV infection treated with anti-viral therapy. Patient 1 did not respond to 48 weeks of therapy with pegylated interferon and ribavirin. Plasma sFGL2 levels in patient 1 were very high prior to initiation of therapy, $>300 \mathrm{ng} / \mathrm{mL}$, and remained high throughout treatment and at 6 months posttreatment. In contrast, patient 2 had sFGL2 levels of less than $100 \mathrm{ng} / \mathrm{mL}$ prior to initiation of treatment; the level of sFGL2 fell within 4 weeks of therapy to levels seen in healthy controls, and levels of sFGL2 remained very low after completion of therapy.

We now also have preliminary pathological evidence for the interplay between Treg cells and FGL2 in patients with HCV infection. Figure 5 shows the co-expression of FGL2 (membrane and cytoplasmic) and Foxp3 (nuclear), the master transcription factor of Treg cells, in some of the inflammatory cells in the liver of a patient with chronic HCV infection.

In a preliminary study, we found that patients

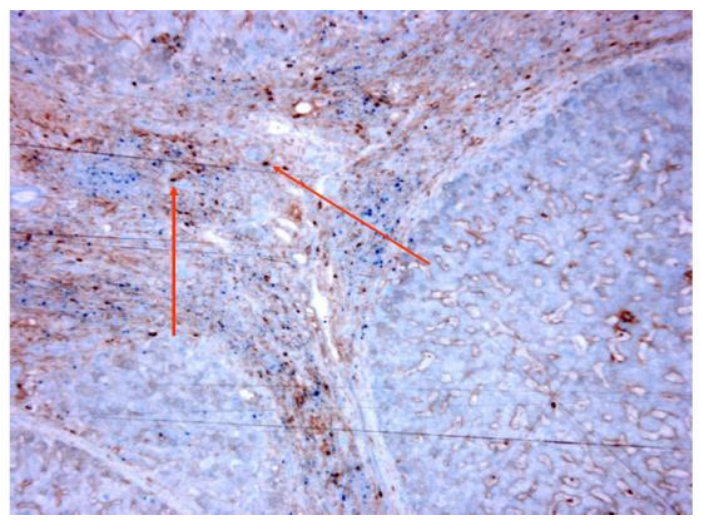

Figure 5. Pathological evidence for the interplay between Treg cells and FGL2 in patients with HCV infection. Figure shows immunohistochemistry staining of FGL2 (brown = membrane and cytoplasmic) and Foxp3 (blue = nuclear) in an explanted liver from an HCV patient. Some lymphocytes (arrows) co-express both FGL2 and Foxp3.

with high levels of FGL2 in the explanted liver are much more likely to have rapid and aggressive recurrence of $\mathrm{HCV}$ that responds poorly to treatment. Examples of the differences in the degree of FGL2 expression in the explanted liver of two patients and the correlation with the posttransplant clinical course are illustrated in Figure 6. Panel A shows a chronic HCV patient with many FGL2-positive cells (brown cells) in the explant who developed aggressive recurrent disease that did not respond to treatment. Panel B shows another chronic HCV patient who had only a few scattered FGL2-positive cells (brown cells) in the explanted liver and has not required any treatment for recurrent HCV infection.

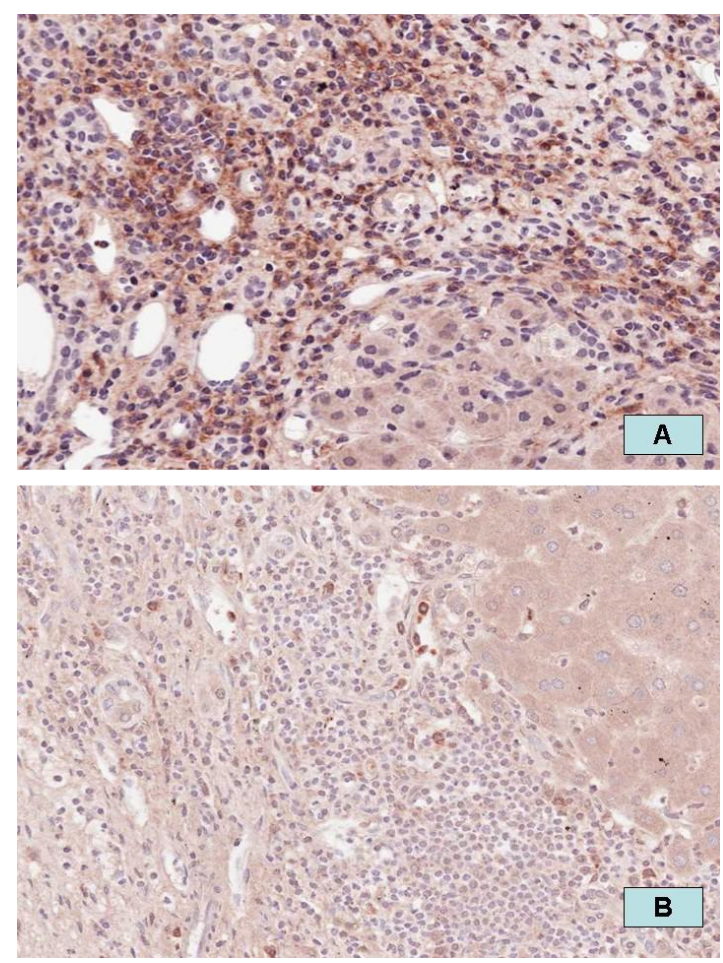

Figure 6. Increased expression of FGL2 in the explanted liver correlates with severity and recurrence of HCV infection. A: Chronic HCV patient with many FGL2-positive cells (brown cells) in the explant, who developed aggressive recurrent disease that did not respond to treatment. B: Chronic HCV patient who had only a few scattered FGL2-positive cells (brown cells) in the explant and has not required any treatment for recurrent $\mathrm{HCV}$ infection. Staining for FGL2 was performed by standard immunohistochemistry using a monoclonal anti-FGL2 antibody and the horse-radish immunoperoxidase method; magnification $\times 300$.

\section{FGL2: MECHANISM OF ACTION}

Based upon the data collected to date, it has been shown that FGL2 is integral to both the innate and the adaptive immune responses. This is not surprising as FGL2 is a molecule that has been conserved through evolution from single-cell organisms such as the ameba to higher primates. We propose a mechanistic model by which FGL2 exerts its immunoregulatory effects (Figure 7). 


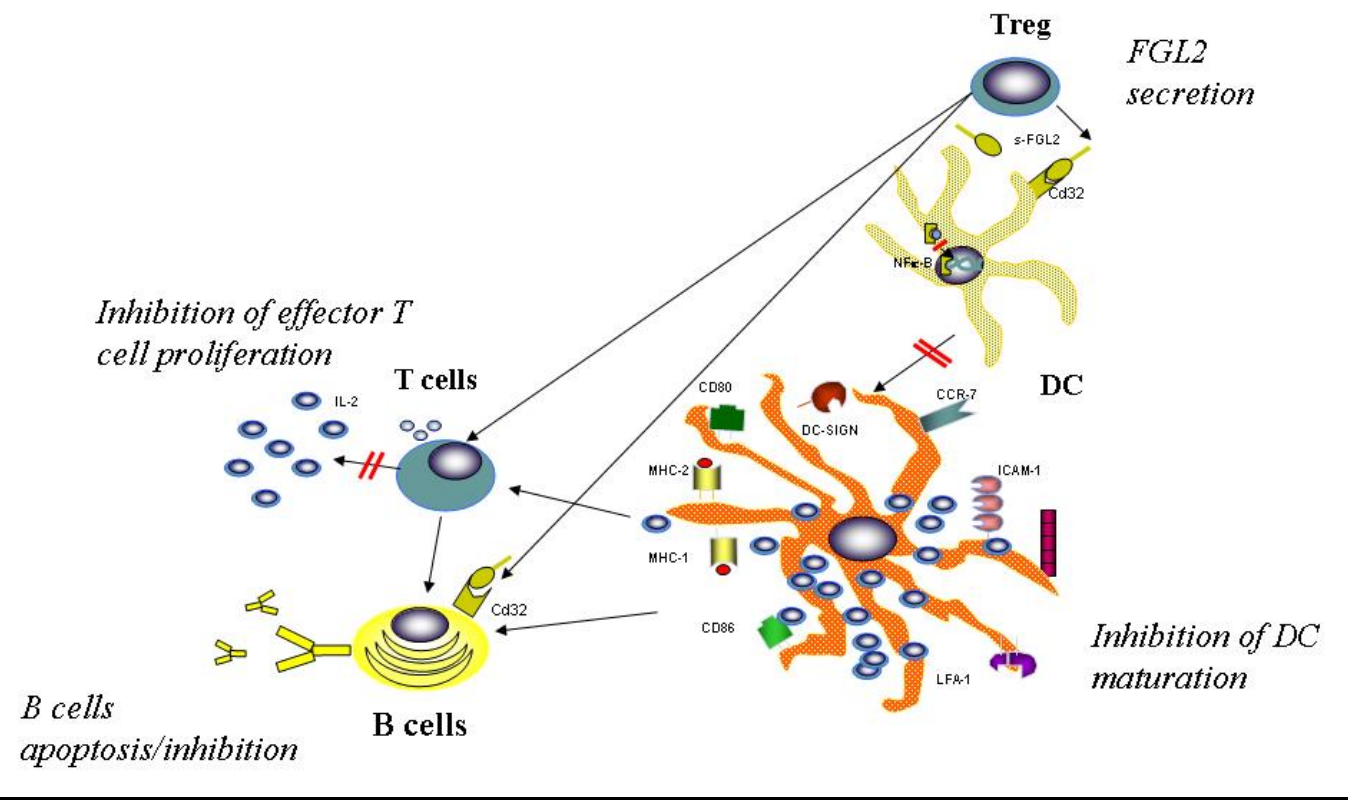

Figure 7. A proposed model of FGL2 immunoregulatory activities. Treg production of FGL2 downregulates adaptive immune responses through binding to the inhibitory FcyRIIB receptor, which is expressed on antigen-presenting cells. The suppressive activities of FGL2 result in inhibition of the immune response against the $\mathrm{HCV}$, leading to viral persistence and chronic infection. DC, dendritic cells.

Treg cells secrete FGL2, which then binds to the inhibitory FcyRIIB receptor expressed on DC. Binding of FGL2 to FcyRIIB down-regulates immune activation of DC as indicated by inhibition of expression of the maturation markers CD80, CD86, and MHCII. This suppressive effect of FGL2 on DC was shown to be mediated through inhibition of NF- $\mathrm{KB}$ nuclear translocation. $47 \mathrm{DC}$ that are exposed to FGL2 would be therefore less effective in inducing proliferation and effector function of helper and cytotoxic T lymphocytes. Suppression of helper $\mathrm{T}$ cell activation and DC maturation by FGL2 could lead indirectly to inhibition of T-dependent and T-independent B cell responses, respectively. As demonstrated by our in vitro studies, FGL2 can also directly induce apoptosis in B cells upon binding to the inhibitory FcyRIIB receptor, which is known to be expressed on B cells. The indirect and direct suppressive activities of FGL2 result in inhibition of the immune response against the $\mathrm{HCV}$, leading to viral persistence and chronic infection.

\section{CONCLUSIONS AND FUTURE DIRECTIONS}

$\mathrm{HCV}$ infection is a major world health problem and the leading cause of HCC worldwide. Disturbances in Treg cell function or number have now been shown to contribute to failure of clearance of HCV and the development of chronic hepatitis. FGL2 has been shown to be an important effector molecule of Treg cells and was demonstrated to play a key role in the pathogenesis of both experimental and human viral hepatitis. Measurement of levels of sFGL2 in plasma of patients appears to predict both the course of HCV disease and response to anti-viral therapy, and, as such, FGL2 as a biomarker may become an important diagnostic reagent in the management of HCV patients. Furthermore, the studies show that inhibition of FGL2 improves outcomes to experimental hepatitis and thus provide impetus for generation of reagents to inhibit FGL2 in patients with acute and chronic hepatitis $\mathrm{B}$ and $\mathrm{C}$ virus infection either alone or in combination 
with present anti-viral agents. As expression of FGL2 has been shown to be associated with other diseases including HIV, SARS, and cancer, measurement of sFGL2 levels and development of reagents that interfere with FGL2 may have even broader applicability.

\section{REFERENCES}

1. Lavanchy D. The global burden of hepatitis C. Liver Int 2009;29 Suppl 1:74-81.

2. Strader DB, Wright T, Thomas DL, Seeff LB. Diagnosis, management, and treatment of hepatitis $\mathrm{C}$. Hepatology 2004;39:1147-71.

3. Fried MW. Side effects of therapy of hepatitis C and their management. Hepatology 2002;36(5 Suppl 1):S237-44. doi:10.1053/jhep.2002.36810

4. Fried MW, Shiffman ML, Reddy KR, et al. Peginterferon alfa-2a plus ribavirin for chronic hepatitis C virus infection. N Engl $\mathrm{J}$ Med 2002; 347:975-82.

5. Hadziyannis SJ, Sette H, Jr., Morgan TR, et al. Peginterferon-alpha2a and ribavirin combination therapy in chronic hepatitis C: a randomized study of treatment duration and ribavirin dose. Ann Intern Med 2004;140:346-55.

6. Manns MP, McHutchison JG, Gordon SC, et al. Peginterferon alfa-2b plus ribavirin compared with interferon alfa-2b plus ribavirin for initial treatment of chronic hepatitis C: a randomised trial. Lancet 2001;358:958-65. doi:10.1016/So140-6736 (01)06102-5

7. De MN, Colantoni A, Idilman R, Friedlander L, Harig J, Van Thiel DH. Impaired response to highdose interferon treatment in African-Americans with chronic hepatitis C. Hepatogastroenterology 2002;49:788-92.

8. Kinzie JL, Naylor PH, Nathani MG, et al. African Americans with genotype 1 treated with interferon for chronic hepatitis $\mathrm{C}$ have a lower end of treatment response than Caucasians. J Viral Hepat 2001;8:264-9.

9. Missiha SB, Ostrowski M, Heathcote EJ. Disease progression in chronic hepatitis C: modifiable and nonmodifiable factors. Gastroenterology 2008; 134:1699-714.

10. Reddy KR, Hoofnagle JH, Tong MJ, et al. Racial differences in responses to therapy with interferon in chronic hepatitis C. Consensus Interferon Study Group. Hepatology 1999;30:787-93.

11. Selzner N, Chen L, Borozan I, Edwards A, Heathcote EJ, McGilvray I. Hepatic gene expression and prediction of therapy response in chronic hepatitis C patients. J Hepatol 2008;48:708-13.

12. de Arias AE, Haworth SE, Belli LS, et al. Killer cell immunoglobulin-like receptor genotype and killer cell immunoglobulin-like receptor-human leukocyte antigen $\mathrm{C}$ ligand compatibility affect the severity of hepatitis $\mathrm{C}$ virus recurrence after liver transplantation. Liver Transpl 2009;15:390-9.

13. Rehermann B, Nascimbeni M. Immunology of hepatitis B virus and hepatitis C virus infection. Nat Rev Immunol 2005;5:215-29.

14. Shoukry NH, Cawthon AG, Walker CM. Cell-mediated immunity and the outcome of hepatitis $\mathrm{C}$ virus infection. Annu Rev Microbiol 2004;58:391424. doi:10.1146/annurev.micro.58.030603.123 $\underline{836}$

15. Thimme R, Bukh J, Spangenberg HC, et al. Viral and immunological determinants of hepatitis $\mathrm{C}$ virus clearance, persistence, and disease. Proc Natl Acad Sci U S A 2002;99:15661-8.

16. Grakoui A, Shoukry NH, Woollard DJ, et al. HCV persistence and immune evasion in the absence of memory T cell help. Science 2003;302:659-62. doi:10.1126/science.1088774

17. Diepolder HM, Zachoval R, Hoffmann RM, Jung MC, Gerlach T, Pape GR. The role of hepatitis C virus specific $\mathrm{CD}_{4}+\mathrm{T}$ lymphocytes in acute and chronic hepatitis C. J Mol Med 1996;74:583-8. doi:10.1007/s001090050062

18. Wedemeyer H, He XS, Nascimbeni M, et al. Impaired effector function of hepatitis $\mathrm{C}$ virus-specific CD8+ $\mathrm{T}$ cells in chronic hepatitis $\mathrm{C}$ virus infection. J Immunol 2002;169:3447-58.

19. Zajac AJ, Blattman JN, Murali-Krishna K, et al. Viral immune evasion due to persistence of activated $\mathrm{T}$ cells without effector function. $\mathrm{J}$ Exp Med 1998;188:2205-13.

20. Rollier C, Depla E, Drexhage JA, et al. Control of heterologous hepatitis $\mathrm{C}$ virus infection in chimpanzees is associated with the quality of vaccineinduced peripheral T-helper immune response. $\mathrm{J}$ Virol 2004;78:187-96. doi:10.1128/JVI.78.1.187196.2004

21. Jaekel HP, Klopsch T, Benkenstein B, et al. Reactivities to the Sm autoantigenic complex and the synthetic SmD1-aa83-119 peptide in systemic lupus erythematosus and other autoimmune diseases. J Autoimmun 2001;17:347-54. doi:10.1006/ jaut.2001.0545

22. Kamal SM, Rasenack JW, Bianchi L, et al. Acute hepatitis $\mathrm{C}$ without and with schistosomiasis: correlation with hepatitis C-specific CD4(+) T-cell and 
cytokine response. Gastroenterology 2001;121: 646 -56. doi:10.1053/gast.2001.27024

23. Rosen HR, Hinrichs DJ, Gretch DR, et al. Association of multispecific $\mathrm{CD}_{4}(+)$ response to hepatitis $\mathrm{C}$ and severity of recurrence after liver transplantation. Gastroenterology 1999;117:926-32.

24. Gruener NH, Jung MC, Schirren CA. Recurrent hepatitis $\mathrm{C}$ virus infection after liver transplantation: natural course, therapeutic approach and possible mechanisms of viral control. J Antimicrob Chemother 2004 Jul;54(1):17-20.

25. Sakaguchi S, Setoguchi R, Yagi H, Nomura T. Naturally arising Foxp3-expressing CD25+CD4+ regulatory $\mathrm{T}$ cells in self-tolerance and autoimmune disease. Curr Top Microbiol Immunol 2006; 305:51-66.

26. Cabrera R, Tu Z, Xu Y, et al. An immunomodulatory role for $\mathrm{CD} 4(+) \mathrm{CD} 25(+)$ regulatory $\mathrm{T}$ lymphocytes in hepatitis $\mathrm{C}$ virus infection. Hepatology 2004;40:1062-71. doi:10.1002/hep.20454

27. Sakaguchi S. Regulatory T cells: mediating compromises between host and parasite. Nat Immunol 2003;4:10-11.

28. Boettler T, Spangenberg HC, Neumann-Haefelin $\mathrm{C}$, et al. $\mathrm{T}$ cells with a CD4+CD25+ regulatory phenotype suppress in vitro proliferation of virus-specific CD8+ T cells during chronic hepatitis $\mathrm{C}$ virus infection. J Virol 2005;79:7860-7. doi:10.1128/ JVI.79.12.7860-7867.2005

29. Bolacchi F, Sinistro A, Ciaprini C, et al. Increased hepatitis $\mathrm{C}$ virus (HCV)-specific $\mathrm{CD} 4+\mathrm{CD} 25+$ regulatory $\mathrm{T}$ lymphocytes and reduced $\mathrm{HCV}$-specific $\mathrm{CD} 4+\mathrm{T}$ cell response in $\mathrm{HCV}$-infected patients with normal versus abnormal alanine aminotransferase levels. Clin Exp Immunol 2006; 144 :18896. doi:10.1111/j.1365-2249.2006.03048.x

30. Demirkiran A, Kok A, Kwekkeboom J, et al. Low circulating regulatory $\mathrm{T}$-cell levels after acute rejection in liver transplantation. Liver Transpl 2006;12:277-84. doi:10.1002/lt.20612

31. Shevach EM. Mechanisms of foxp3 $+\mathrm{T}$ regulatory cell-mediated suppression. Immunity 2009;30: 636-45. doi:10.1016/j.immuni.2009.04.010

32. Shevach EM. CD4+ CD25+ suppressor T cells: more questions than answers. Nat Rev Immunol 2002;2389-400.

33. Fontenot JD, Rasmussen JP, Gavin MA, Rudensky AY. A function for interleukin 2 in Foxp3-expressing regulatory $\mathrm{T}$ cells. Nat Immunol 2005;6:1142-51. doi:10.1038/ni1263

34. Herman AE, Freeman GJ, Mathis D, Benoist C. $\mathrm{CD} 4+\mathrm{CD} 25+\mathrm{T}$ regulatory cells dependent on ICOS promote regulation of effector cells in the prediabetic lesion. J Exp Med 2004;199:1479-89. doi:10. 1084/jem.20040179

35. Shalev I, Liu H, Koscik C, et al. Targeted deletion of fgl2 leads to impaired regulatory $\mathrm{T}$ cell activity and development of autoimmune glomerulonephritis. J Immunol 2008;180:249-60.

36. Shalev I, Wong KM, Foerster K, et al. The novel $\mathrm{CD} 4+\mathrm{CD} 25+$ regulatory $\mathrm{T}$ cell effector molecule fibrinogen-like protein 2 contributes to the outcome of murine fulminant viral hepatitis. Hepatology 2009;49:387-97. doi:10.1002/hep.22684

37. Koyama T, Hall LR, Haser WG, Tonegawa S, Saito H. Structure of a cytotoxic T-lymphocyte-specific gene shows a strong homology to fibrinogen beta and gamma chains. Proc Natl Acad Sci U S A 1987; 84:1609-13. doi:10.1073/pnas.84.6.1609

38. Yuwaraj S, Ding J, Liu M, Marsden PA, Levy GA. Genomic characterization, localization, and functional expression of FGL2, the human gene encoding fibroleukin: a novel human procoagulant. Genomics 2001;71:330-8. doi:10.1006/geno.2000. 6444

39. Liu H, Shalev I, Manuel J, et al. The FGL2-FcgammaRIIB pathway: a novel mechanism leading to immunosuppression. Eur J Immunol 2008;38: 3114-26. doi:10.1002/eji.200838338

40. Marazzi S, Blum S, Hartmann R, et al. Characterization of human fibroleukin, a fibrinogen-like protein secreted by T lymphocytes. J Immunol 1998; 161:138-47.

41. Levy GA, Liu M, Ding J, et al. Molecular and functional analysis of the human prothrombinase gene (HFGL2) and its role in viral hepatitis. Am J Pathol 2000;156:1217-25.

42. Chan CW, Chan MW, Liu M, et al. Kinetic analysis of a unique direct prothrombinase, fgl2, and identification of a serine residue critical for the prothrombinase activity. J Immunol 2002;168: 5170-7.

43. Clark DA, Foerster K, Fung L, et al. The fgl2 prothrombinase/fibroleukin gene is required for lipopolysaccharide-triggered abortions and for normal mouse reproduction. Mol Hum Reprod 2004;10:99-108. doi:10.1093/molehr/gaho13

44. Ghanekar A, Mendicino M, Liu H, et al. Endothelial induction of fgl2 contributes to thrombosis during acute vascular xenograft rejection. J Immunol 2004;172:5693-701.

45. Marsden PA, Ning Q, Fung LS, et al. The Fgl2/fibroleukin prothrombinase contributes to immunologically mediated thrombosis in experi- 
mental and human viral hepatitis. J Clin Invest 2003;112:58-66.

46. Mendicino M, Liu M, Ghanekar A, et al. Targeted deletion of Fgl-2/fibroleukin in the donor modulates immunologic response and acute vascular rejection in cardiac xenografts. Circulation 2005; 112:248-56. doi:10.1161/CIRCULATIONAHA.105.5.34271

47. Chan CW, Kay LS, Khadaroo RG, et al. Soluble fibrinogen-like protein 2/fibroleukin exhibits immunosuppressive properties: suppressing $\mathrm{T}$ cell proliferation and inhibiting maturation of bone marrow-derived dendritic cells. J Immunol 2003; 170:4036-44.

48. Chen WJ, Yang JY, Lin JH, et al. Nasopharyngeal shedding of severe acute respiratory syndrome-associated coronavirus is associated with genetic polymorphisms. Clin Infect Dis 2006;42:1561-9. doi:10.1086/503843

49. Li Q, Smith AJ, Schacker TW, et al. Microarray analysis of lymphatic tissue reveals stage-specific, gene expression signatures in HIV-1 infection. J Immunol 2009;183:1975-82. doi:10.4049/ jimmunol.0803222

50. Kohno T, Moriuchi R, Katamine S, Yamada Y, Tomonaga M, Matsuyama T. Identification of genes associated with the progression of adult $\mathrm{T}$ cell leukemia (ATL). Jpn J Cancer Res 2000;91:1103-10.

51. Suzuki A, Ji G, Numabe Y, Ishii K, Muramatsu M, Kamoi K. Large-scale investigation of genomic markers for severe periodontitis. Odontology 2004;92:43-7. doi:10.1007/s10266-004-0035-4

52. Chaerkady R, Harsha HC, Nalli A, et al. A quantitative proteomic approach for identification of potential biomarkers in hepatocellular carcinoma. J Proteome Res 2008;7:4289-98. doi:10.1021/pr80 $\underline{0197 Z}$

53. Zheng Y, Josefowicz SZ, Kas A, Chu TT, Gavin MA, Rudensky AY. Genome-wide analysis of Foxp3 target genes in developing and mature regulatory $\mathrm{T}$ cells. Nature 2007;445:936-40. doi:10.1038/ nature 05563

54. Denning TL, Granger SW, Mucida D, et al. Mouse TCRalphabeta+CD8alphaalpha intraepithelial lymphocytes express genes that down-regulate their antigen reactivity and suppress immune responses. J Immunol 2007;178:4230-9.
55. Levy GA, MacPhee PJ, Fung LS, Fisher MM, Rappaport AM. The effects of mouse hepatitis virus type 3 on the microcirculation of the liver in inbred strains of mice. Adv Exp Med Biol 1984;173:397-9.

56. Parr RL, Fung L, Reneker J, Myers-Mason N, Leibowitz JL, Levy G. MHV-3 induced prothrombinase is encoded by musfiblp. Adv Exp Med Biol 1995;380:151-157.

57. Pope M, Rotstein O, Cole E, et al. Pattern of disease after murine hepatitis virus strain 3 infection correlates with macrophage activation and not viral replication. J Virol 1995;69:5252-60.

58. Pope M, Marsden PA, Cole E, et al. Resistance to murine hepatitis virus strain 3 is dependent on production of nitric oxide. J Virol 1998;72:708490.

59. Levy GA, Leibowitz JL, Edgington TS. Induction of monocyte procoagulant activity by murine hepatitis virus type 3 parallels disease susceptibility in mice. J Exp Med 1981;154:1150-63. doi:10.1084/ jem.154.4.1150

6o. Levy GA, MacPhee PJ, Fung LS, Fisher MM, Rappaport AM. The effect of mouse hepatitis virus infection on the microcirculation of the liver. Hepatology 1983;3:964-73.

61. Ning Q, Liu M, Kongkham P, et al. The nucleocapsid protein of murine hepatitis virus type 3 induces transcription of the novel fgl2 prothrombinase gene. J Biol Chem 1999;274:9930-6. doi:10. 1074/jbc.274.15.9930

62. Ning Q, Lakatoo S, Liu M, et al. Induction of prothrombinase fgl2 by the nucleocapsid protein of virulent mouse hepatitis virus is dependent on host hepatic nuclear factor-4 alpha. J Biol Chem 2003;278:15541-9. doi:10.1074/jbc.M212806200

63. Ning Q, Luo XP, Wang ZM, et al. [The study of ciselement $\mathrm{HNF}_{4}$ in the regulation of mfg12 prothrombinase/fibroleukin gene expression in response to nucleocapsid protein of $\mathrm{MHV}-3]$. Zhonghua Yi Xue Za Zhi 2003;83:678-83.

64.Ning Q, Berger L, Luo X, et al. STAT1 and STAT3 alpha/beta splice form activation predicts host responses in mouse hepatitis virus type 3 infection. J Med Virol 2003;69:306-12. doi:10.1002/jmv. $\underline{10290}$ 